\title{
Hypobiosis induction alters the protein profile of Ostertagia ostertagi (Nematoda: Trichostrongylidae)
}

\author{
Marcela C. Dopchiz, Alberto E. Parma and César A. Fiel \\ Departmento de Sanidad Animal, Facultad Ciencias Veterinarias, Universidad Nacional del Centro de la Provincia de Buenos \\ Aires, 7000 Tandil, Argentina
}

Key words: Ostertagia ostertagi, proteins, hypobiosis, bovine

\begin{abstract}
The appearance of variations in the protein profile of Ostertagia ostertagi (Stiles, 1892) infective larvae $\left(\mathrm{L}_{3}\right)$, which were induced by hypobiosis triggering factors, was evaluated by means of SDS-PAGE and densitometric analysis. Area integration analyses of their protein profiles was carried out between 66 and $77 \mathrm{kDa}$. Important quantitative variations were identified in the protein levels of the induced larvae, where a 5.25 fold increase compared to the control was observed. Two 75.4 and $70 \mathrm{kDa}$ protein bands were found which exceeded the control profile by 4.5 and 44 fold, respectively. This fact suggests that the changes brought about in the process of hypobiosis induction are restricted. This work demonstrates changes at a molecular level corresponding with biological changes induced by conditions causing $O$. ostertagi hypobiosis.
\end{abstract}

The bovine parasitic nematodes of major economic importance in temperate regions of the world are: the trichostrongyles Ostertagia ostertagi (Stiles, 1892) and Cooperia oncophora (Railliet, 1898), found in the abomasum and the small intestine respectively, and Dictyocaulus viviparus (Bloch, 1782), in the lungs (Armour and Duncan 1987, Fiel et al. 1988, Steffan and Fiel 1994). O. ostertagi is the most pathogenic and economically important agent in temperate cattle areas of Latin America and the rest of the world (Armour 1980, Anderson 1986, Entrocasso 1986).

Ostertagia ostertagi infective larvae $\left(\mathrm{L}_{3}\right)$ can develop at temperatures ranging from $10^{\circ} \mathrm{C}$ to $35^{\circ} \mathrm{C}$. This range of temperatures coincides with the majority of temperate climates during grazing. In Argentina, the incidence area spreads over the southeast of Buenos Aires province, towards the west part of a region called "Pampeana", up to the subtropical area, which comprise the most important cattle regions (Entrocasso and Steffan 1980, Fiel and Steffan 1994a, Suárez 1990, 1994).

The life cycle of this parasite is direct. Depending upon environmental temperature and humidity, the development of the egg, through $\mathrm{L}_{1}$ and $\mathrm{L}_{2}$ to $\mathrm{L}_{3}$, is completed in one to several weeks. $\mathrm{L}_{3}$ can survive on pastures for several months during cold weather and for less time during hot or dry months. Twenty-one days elapse from the time when the animals take in infective larvae $\left(\mathrm{L}_{3}\right)$ with the grass until the prepatent period is completed. However, on certain occasions, ingested larvae temporarily stop their development at the beginning of their fourth stage $\left(\mathrm{L}_{4}\right)$ (Williams 1983, Armour and Duncan 1987, Fiel and Steffan 1994a).

Hypobiosis can be considered as an adapting process where - under certain circumstances - ingested larvae stop their development in the abomasal mucosa for several months as early fourth-stage larvae $\left(\mathrm{L}_{4}\right)$ thus assuring their survival during unfavourable climatic conditions. The arrestment time corresponds to the unfavourable period (Armour 1980, Armour and Duncan 1987, Suárez and Busetti 1989, Suárez 1990, Nari and Rizzo 1994, Fiel and Steffan 1994a). In the northern hemisphere, larvae are inhibited during the end of autumn and winter, renewing their development at the beginning of spring (Randall and Gibbs 1977, Armour 1980, Williams 1983, Smith and Grenfell 1985, Armour and Duncan 1987). On the other hand, in the southern hemisphere, larvae are inhibited in spring and part of the summer, renewing their development from the middle of summer until autumn (Armour 1980, Williams 1983, Smith and Grenfell 1985, Entrocasso 1986, Fiel et al. 1988, Suárez 1990).

There are two theories explaining the causes of hypobiosis: the first one proposes that the effect is produced by the host on the $\mathrm{L}_{4}$ via the immune response; the second one suggests that the seasonal effect acts directly upon the free-living stages, resulting in the arrested development as early $\mathrm{L}_{4}$ in the host (Armour 1978, 1980, Smeal and Donald 1981, Anderson 1986).

In the northern hemisphere, cooling is the environmental stimulus that triggers $\mathrm{L}_{3}$ to become arrested (Armour and Bruce 1974, Armour 1978, 1980, Armour and Duncan 1987). However, in the southern hemisphere, attempts to induce hypobiosis through cooling to bovine nematodes have failed, since this phenomenon naturally occurs during spring not autumn (Smeal and Donald 1982).

Among many interactive factors, both gradual temperature increase and drying-out under semi-arid conditions of the Pampeana region probably deserve more attention (Fiel et al. 1988, Suárez 1990).

Address for correspondence: A.E. Parma, Immunochemistry and Biotechnology, FCV-UNICEN, Pinto 399 , 7000 Tandil, Argentina. Phone: ++54 2293 422357; Fax: ++54 2293 422357; E-mail: aparma@vet.unicen.edu.ar 
Previous results obtained in our laboratory regarding the factors inducing $O$. ostertagi hypobiosis in cattle, show that the stimulus causing this phenomenon occurs while the infective larvae are on the grass and that it depends on daylight and temperature increase at the beginning of spring (Fiel et al. 1997).

Whatever the factors inducing larval inhibition, they probably give rise to changes in larval physiology as well as variations in enzymatic activity and/or in protein profile.

On the other hand, the phenomenon of regulation of genetic expression during development of different species and the observation of quali-quantitative variations in their proteins, is well known (Weeks and Collis 1976, Donelson and Rice-Fitch 1985, Vickerman 1985). Similar situations have been described during the parasite's adaptive response against the pressure of the immune system in infected hosts. Molecular and ultrastructural analyses show that $O$. ostertagi inhibited larvae are metabolically inactive (Armour and Bruce 1974). The influence exerted by factors inducing larval inhibition on either, larval physiology or genetic regulation of proteins, is still unknown. In consequence, the objective of this work is to determine the possible changes in the protein profile of infective larvae $\left(\mathrm{L}_{3}\right)$ induced by hypobiosis triggering factors such as light and temperature.

\section{MATERIALS AND METHODS}

Macrocoprocultures. A six-month-old parasite-free, Holando-Argentino calf, was inoculated with $O$. ostertagi $\mathrm{L}_{3}$ in order to obtain larvae for experimental studies. From the 14th to the 40th day after inoculation, daily samples of faeces were taken and - by means of the method used by Willis and McMaster - egg counts were carried out (Soulsby 1982). Macrocoprocultures were performed with positive samples from both tests.

Recovering of infective $\mathbf{L}_{3}$. Because of the great volumes of daily macrocoprocultures, larval recovery was carried out by two alternative ways, namely: Roberts and O'Sullivan modified method and Baermann method (Fiel and Steffan 1994b).

Experimental hypobiosis induction. Infective larvae recovered from the macrocoprocultures were evenly distributed on Petri dishes and hypobiosis induced under laboratory conditions. A sample called "induced population" (IP) was first incubated at $9^{\circ} \mathrm{C}$ for three weeks, with photoperiods of 11 hours 36 minutes; then for another threeweek period at $13^{\circ} \mathrm{C}$ with 14 hour photoperiods. Temperature conditions were attained by means of culture chambers by a 60 W 230 Volts "day-light" lamp. These conditions induce hypobiosis in $O$. ostertagi. The other sample called "control population" (CP) was kept in a refrigerator at $4^{\circ} \mathrm{C}$ for six weeks and in a complete darkness.

Filtration and purification. Samples were filtered after the induction period was completed. A glass-fibre pre-filter with a pore of $1 \mu \mathrm{m}$ and a diameter of $124 \mathrm{~mm}$ (MSI) was used. Trichostrongylid larvae were held back, removing extraction liquid and microorganisms. Dry pre-filters were put upside down over a paper towel and the latter on a mesh in a glass funnel, thus allowing the recovery of the larvae following Baermann method.

SDS-PAGE. Larvae were electrophoresed according to Hames (1988), in $7.5,10$ or $12 \%$ (w/v) acrylamidebisacrylamide gel under denaturing and reducing conditions (0.17 M SDS and 0.71 M 2-mercaptoethanol). The running buffer was as described by Laemmli (1970) and Hames (1988). Samples were run in a Hoefer SE250 vertical slab gel unit at $20 \mathrm{~mA}$ per gel.

To optimise band resolution, different loading volumes were tested $(5,10,15$ and $20 \mu \mathrm{l}$ per well) with a concentration of $6 \times 10^{3}$ larvae $\mathrm{ml}^{-1}$. For this, larvae were resuspended in Laemmli buffer and heated at $100^{\circ} \mathrm{C}$ for 6 minutes. They were sonically disrupted for 1 minute and heating was repeated once more $(2 \mathrm{~min})$. Finally, two $10 \%$ acrylamidebisacrylamide gels were run, loading the wells with the material corresponding to 150 and 340 larvae of each treatment. A MW-SDS-200 kit (Sigma 30:200 kDa) was used as a molecular weight marker.

Once the runs were finished, proteins were stained with Coomassie Brilliant Blue R250 (Sambrook et al. 1989). Protein patterns were analysed in a Hoefer GS300 densitometer giving an output signal where $100 \mathrm{mV}$ corresponded to one unit of absorbance. Area integration analyses were performed using densitometer software.

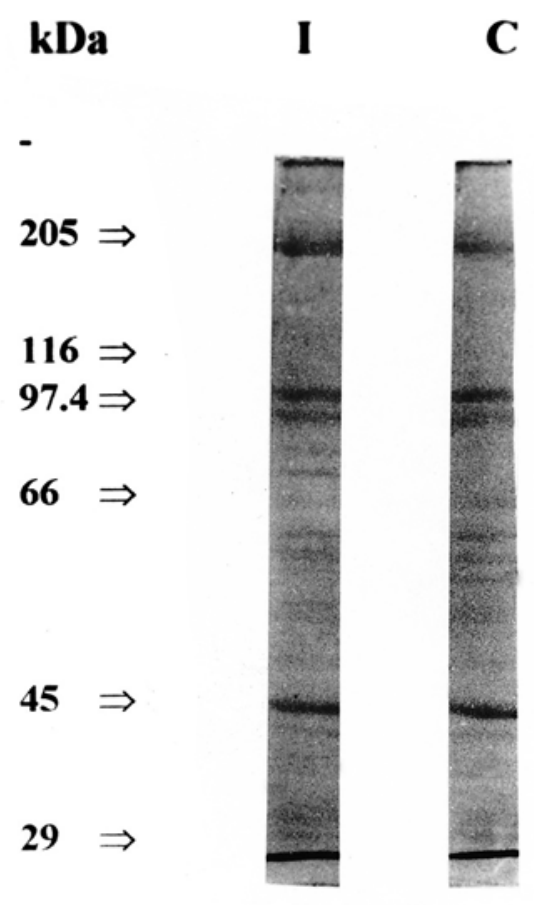

Fig. 1. Coomassie Brilliant Blue R250 pattern of a $10 \%$ SDSPAGE of induced (I) and control (C) Ostertagia ostertagi $\mathrm{L}_{3}$ larval homogenate. Arrows indicate positions corresponding to molecular weight markers (MW-SDS-200 kit, Sigma 30:200 $\mathrm{kDa})$ 


\section{RESULTS}

\section{Analysis of $\mathrm{L}_{3}$ Ostertagia ostertagi protein profile by} SDS-PAGE

Larvae from $O$. ostertagi IP and CP were subjected to SDS-PAGE (10\% acrylamide-bisacrylamide) to analyse their protein profile (Fig. 1).

Fig. 2 shows protein profiles corresponding to the treatments in IP and CP. Each peak represents a protein band. Eventhough a similar pattern can be observed in both scans, the IP profile differs from the control profile in band $\mathrm{A}$, between 66 and $77 \mathrm{kDa}$ bands.
The area of integration under the curve corresponding to band A profiles (Fig. 3a, b) indicates $10.87 \%$ of the total area for the induced population against $2.07 \%$ for the control population of $\mathrm{L}_{3}$. That is to say, there is an increase of 5.25 times in the protein content in band A when larvae are induced to hypobiosis.

The same analysis was made with the software in those zones of Fig. 2, bounded by bands a1 and a2 (Figure 4). Band a1 represents an area of 0.0055 and 0.0245 , whereas band a2 represents a fraction of 0.0005 and 0.0265 , for CP and IP respectively; hence, IP shows an increase of 4.45 times for band a1 and 44.16 times for band a2 compared to CP.

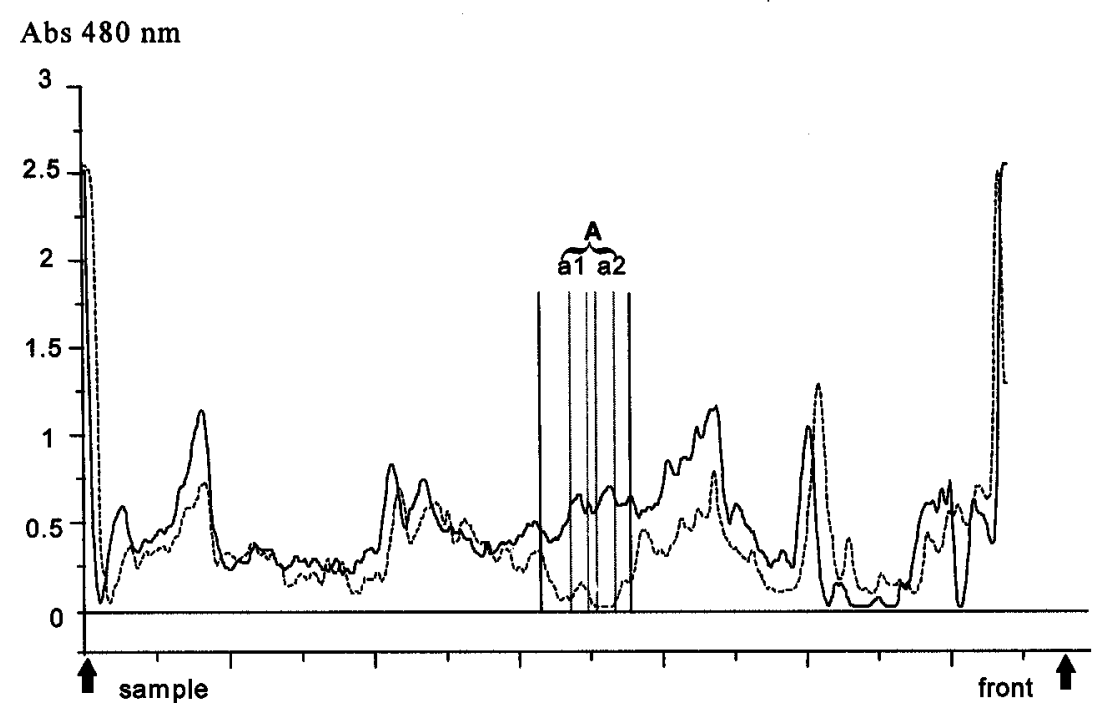

Fig. 2. Densitometry corresponding to the SDS-PAGE. Explanation: $\left(\_\right.$) protein profile of $\mathrm{L}_{3} O$. ostertagi homogenate previously induced to hypobiosis, "induced population" (IP). (......) protein profile of $\mathrm{L}_{3}$ O. ostertagi homogenate "control population" (CP). Arrows show the limits of the protein pattern (left: upper; right: lower). A - place where integration analysis is carried out (shown in Fig. 3).

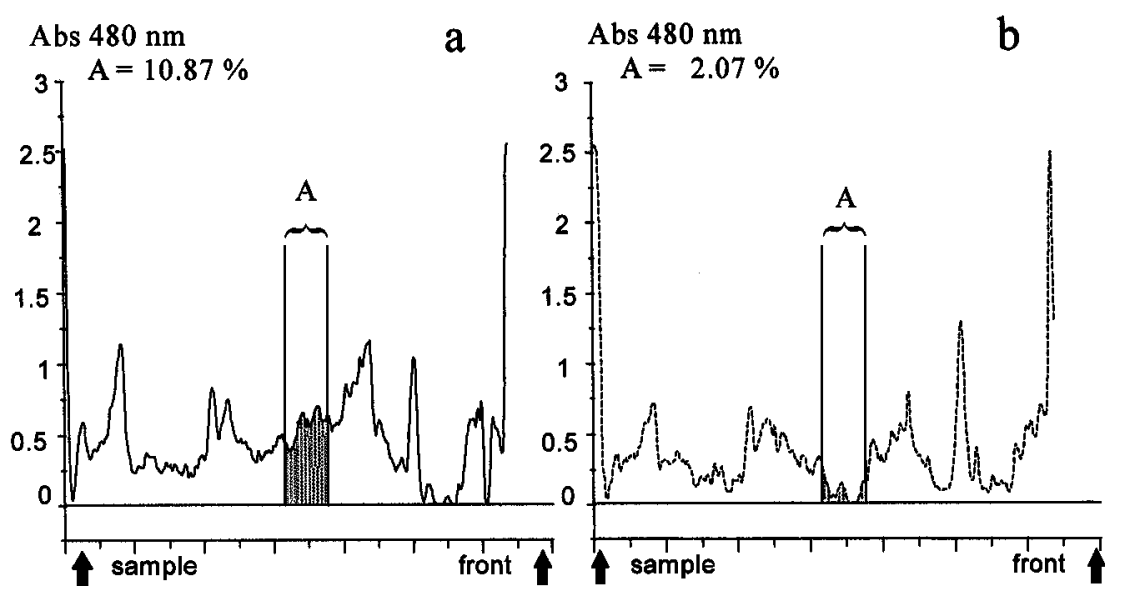

Fig. 3. Integration analysis of band A, comprised between 66 and $77 \mathrm{kDa}$. Study corresponds to the protein profile of: a "induced population"; $\mathbf{b}$-"control population". Values expressed in percentage (\%) show the limited area as fraction of the total area. Arrows show the limits of the protein pattern (left: upper; right: lower). 

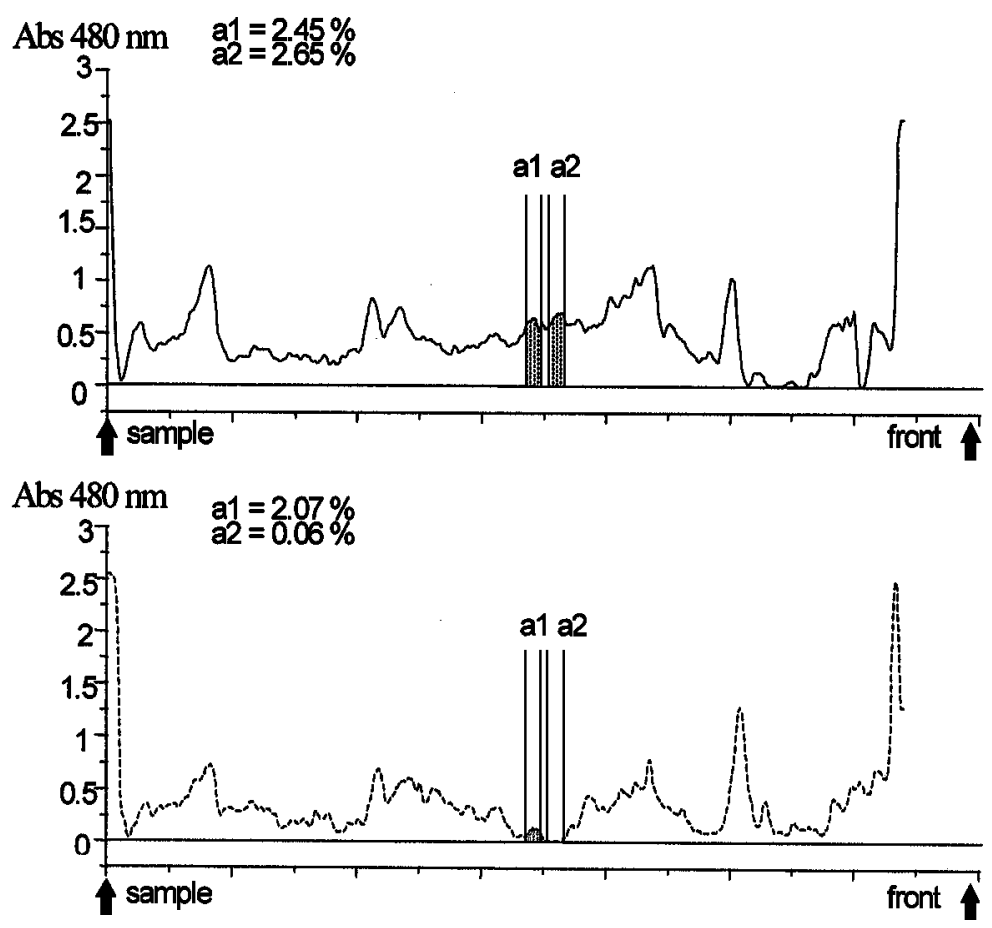

Fig. 4. Integration analysis corresponding to peaks a1 and a2 from band A. Study corresponds to the protein profile of either $\mathbf{a}-$ "induced population", b - "control population". Values expressed in percentage (\%) show the limited area as a fraction of the total area. Arrows show the limits of the protein pattern (left: upper; right: lower).

After comparing regions of interest within band A (peaks a1 and a2) with molecular weight markers and $\mathrm{Rf}$ estimations, two protein bands were determined in peaks a1 and a2 with an approximate molecular weight of 75.4 and $70 \mathrm{kDa}$, respectively.

\section{DISCUSSION}

The aim of this experimental study was to analyse and identify those proteins associated with in vitro hypobiosis induction in Ostertagia ostertagi third-stage larvae. Larvae were prepared for six weeks both receiving or not, physical stimuli to induce hypobiosis. Densitometric analyses of the electrophoretic protein pattern of these populations show quantitative variations in a region of interest (band A) which has a higher protein content -5.25 times more - in the hypobiosis induced $\mathrm{L}_{3}$ than in the control population. Within that region, peaks a1 and $\mathrm{a} 2$ are resolved, with molecular weights of 75.4 and $70 \mathrm{kDa}$, respectively. In a1, the protein content increased 4.45 times, whereas in $\mathrm{a} 2$ the increase is even more significant as the induced content is 44.16 times greater than the control. Since this region is hardly noticeable in the control, we could speculate that its appearance is due to hypobiosis induction stimuli received by the larvae.
To find significant densitometric variation only in a narrow region of the protein profile, shows that the change caused by hypobiosis induction is specific.

These molecular variations were found after subjecting infective larvae to increasing temperature and light, and would support the theory that seasonal effects act directly on the free-living stages. Protein variations produced by hypobiosis induction in Haemonchus contortus were described by Kooyman and Eysker (1995) who exposed these larvae to thermal treatment but without photoperiods. Our protocols were defined previously in this laboratory, in which the effect of time, temperature and light on third-stage larvae in the environment were studied (Fernández et al. 1999).

It remains to be seen if there are more variations in addition to the quantitative ones already found; if there are differences among the kinds of proteins and if these variations are an exclusive consequence of hypobiosis stimuli or if they represent one aspect of the metabolic variations produced when changing into $\mathrm{L}_{3}, \mathrm{~L}_{4}$ or $\mathrm{L}_{4 \mathrm{i}}$ respectively. It would be important to determine the influence that those differences have on the physiological behaviour of the parasite, whether they are secreted proteins or if they constitute one of the antigenic changes that make larvae invisible to the host's immune system. 
In conclusion, proteins could be identified between 66 and $77 \mathrm{kDa}$ which seem to be associated with hypobiosis induction of $O$. ostertagi.
Acknowledgements. Authors thank the technical assistance of María R. Ortiz. This work was supported by the Scientific Research Commission of Buenos Aires Province (CIC) and SECYT-UNCPBA. A. E. Parma is a member of the Scientific Researcher Career of CIC.

\section{REFERENCES}

ANDERSON N. 1986: Aspects of the biology of Ostertagia ostertagi. Ostertagia workshop. Scientific Agenda and Abstracts. Dec. 3-5, University of Maryland. U.S.A. Sec. 1.2, p. 7.

ARMOUR J. 1978: Arrested development in cattle nematodes with special reference to Ostertagia ostertagi. Facts and reflections III. In: F.H.M. Borgsteede, J. Armour, and J. Jansen (Eds.), "Workshop on arrested development of nematodes in sheep and cattle". Parasitological Department of the Centraal Diergeneeskunding Instituut at Lelystad, Lelystad, pp. 77-88.

ARMOUR J. 1980: The epidemiology of helminth disease in farm animals. Vet. Parasitol. 6: 7-46.

ARMOUR J., BRUCE R.G. 1974: Inhibited development in Ostertagia ostertagi infections - a diapause phenomenon in a nematode. Parasitology 69: 161-174.

ARMOUR J., DUNCAN M. 1987: Arrested larval development in cattle nematodes. Parasitol. Today 3: 171-176.

DONELSON J., RICE-FITCH A. 1985: Molecular biology of the trypanosome antigenic variation. Microbiol. Rev. 49: 107-125.

ENTROCASSO C.M. 1986: Epidemiology and control of ostertagiasis in South America. Ostertagia workshop. Scientific Agenda and Abstracts. Dec. 3-5, University of Maryland, Sec. 4.2, p. 11.

ENTROCASSO C., STEFFAN P. 1980: Parasitosis gastrointestinal en bovinos. Rev. Argent. Prod. Anim. 1: 274286.

FERNANDEZ A.S., FIEL C.A., STEFFAN P.E. 1999: Study on the inductive factors of hypobiosis of Ostertagia ostertagi in cattle. Vet. Parasitol. 81: 295-307.

FIEL C.A., FERNANDEZ A.S., STEFFAN P.E., GONZALEZ F., FERREYRA D.A. 1997: Hipobiosis de Ostertagia ostertagi: estudio de aspectos relacionados a su inducción natural y artificial. Rev. Brasil. Parasitol. Vet. 6 (Suppl. 1): 202.

FIEL C.A., STEFFAN P.E. 1994a: Epidemiología de los nematodes gastrointestinales en la Pampa Húmeda. In: A. Nari and C.A. Fiel (Eds.), Enfermedades parasitarias de importancia económica en bovinos. Bases epidemiológicas para su prevención y control. Hemisferio Sur, Montevideo, Uruguay, pp. 67-94.

FIEL C.A., STEFFAN P.E. 1994b: Guía de procedimientos para el diagnóstico de nematodes en bovinos. C. A. Fiel, P. E. Steffan (Eds.). Hoechst Argentina, Buenos Aires, pp. 113.

FIEL C.A., STEFFAN P.E., VERCESSI H.M., AMBRUSTOLO R.R., CATANIA P., CASARO A.P., ENTROCASSO C.M., BIONDANI C.A. 1988: Variación estacional del parasitismo interno de los bovinos en el sudeste de la provincia de Buenos Aires (Argentina) con especial referencia al fenómeno de "hipobiosis". Rev. Med. Vet. (B. Aires) 19: 57-64.

HAMES B.D. 1988: An introduction to polyacrylamide gel electrophoresis. In: B.D. Hames and D. Rickwood (Eds.), Gel Electrophoresis of Proteins - A Practical Approach. IRL Press, Oxford, pp. 1-86.

KOOYMAN F.N.J., EYSKER M. 1995: Analysis of proteins related to conditions for arrested development and differentiation in Haemonchus contortus by twodimensional gel electrophoresis. Int. J. Parasitol. 25: 561568.

LAEMMLI U. 1970: Cleavage of structural proteins during the assembly of the head of bacteriophage $T_{4}$. Nature 227 : 680-685.

NARI A., RIZZO E. 1994: Epidemiología y control de nematodes gastrointestinales. In: A. Nari and C.A. Fiel (Eds.), Enfermedades parasitarias de importancia económica en bovinos. Bases epidemiológicas para su prevención y control. Hemisferio Sur, Montevideo, Uruguay, pp. 155-201.

RANDALL R.W., GIBBS C.H. 1977: Occurrence and seasonal behavior of gastrointestinal nematodes infecting Maine dairy cattle. Am. J. Vet. Res. 38: 1665-1668.

SAMBROOK J., FRITSH E.F., MANIATIS T. 1989: Detection and analysis of proteins expressed from cloned geles. In: J. Sambrook, E.F. Fritsh and T. Maniatis (Eds.), Molecular Cloning - A Laboratory Manual. Cold Spring Harbor Laboratory Press, New York, pp. 18.1-18.88.

SMEAL M.G., DONALD A.D. 1981: Effects on inhibition of development of the transfer of Ostertagia ostertagi between geographical regions of Australia. Parasitology 82: 389-399.

SMEAL M.G., DONALD A.D. 1982: Inhibition of development of Ostertagia ostertagi - effect of temperature on the infective larval stage. Parasitology 85 : 27-32.

SMITH G., GRENFELL B.T. 1985: The population biology of Ostertagia ostertagi. Parasitol. Today 1: 76-81.

SOULSBY E.J.L. 1982: Helminths, Arthropods and Protozoa of Domesticated Animals. Seventh edition. Bailliere Tindall, London, 809 pp.

STEFFAN P., FIEL C.A. 1994: Efectos en la producción y control de nematodes gastrointestinales en bovinos. In: A. Nari and C.A. Fiel (Eds.), Enfermedades parasitarias de importancia económica en bovinos. Bases epidemiológicas para su prevención y control. Hemisferio Sur, Montevideo, Uruguay, pp. 131-153.

SUÁREZ V.H. 1990: Inhibition patterns and seasonal availability of nematodes for beef cattle grazing on Argentina's western pampas. Int. J. Parasitol. 20: 10311036. 
SUÁREZ V.H. 1994: Epidemiología de los nematodes gastrointestinales de la región Subhúmeda y Semiárida Pampeana. In: A. Nari and C.A. Fiel (Eds.), Enfermedades parasitarias de importancia económica en bovinos. Bases epidemiológicas para su prevención y control. Hemisferio Sur, Montevideo, Uruguay, pp. 95-114.

SUÁREZ V.H., BUSETTI M.R. 1989: Epizootiología y efecto de los nematodes gastrointestinales en la recría de terneras en la región semiárida pampeana. Rev. Argent. Prod. Anim. 9: 149-158.

Received 1 July 1999
VICKERMAN K. 1985: Developmental cycles and biology of pathogenic trypanosomes. Brit. Med. Bull. 41: 105-114.

WEEKS D.P., COLLIS P.S. 1976: Induction of microtubule protein synthesis in Chlamydomonas reinhardii during flagellar regeneration. Cell 9: 15-27.

WILLIAMS J.C. 1983: Internal parasites of cattle. J.C. Williams (Ed.). American Hoechst Corporation, Animal Health Division, Louisiana, USA, pp. 1-19.

Accepted 2 February 2000 